\title{
ФАКТОРЫ РИСКА ЛЕТАЛЬНОГО ИСХОДА У ПАЦИЕНТОВ С ВНЕБОЛЬНИЧНОЙ ПНЕВМОНИЕЙ
}

\section{RISK FACTORS FOR DEATH IN PATIENTS WITH COMMUNITY-ACQUIRED PNEUMONIA}

\section{E. Vishneva \\ E. Yegorova \\ A. Kalabina \\ V. Redkina}

Summary. Community-acquired pneumonia of bacterial etiology is of great epidemiological and medical significance even against the background of a changed epidemiological situation in the world due to the widespread spread of SARS-CoV-2 viral pneumonia. Despite the possibility of establishing an accurate etiological diagnosis and effective antibiotic therapy, morbidity and mortality rates associated with community-acquired pneumonia remain high. Most of the risk factors for mortality from community-acquired pneumonia have long been identified; they include conditions such as respiratory failure, the presence of certain concomitant diseases, social adaptation of patients, but there are also a number of specific points for each region. Our article was to assess local risk factors for mortality from CAP and to carry out a comparative analysis of the data with literature sources.

Keywords: community-acquired pneumonia, mortality, risk factors.
Вишнева Елена Михайловна

Д.м.н., дочент, врач-кардиолог высшей категории, ФГБОУ ВПО «Уральский Государственный Медицинский Университет»; главный врач, сеть клиник ООО «Семейная клиника», г. Екатеринбург e.m.vishneva@mail.ru

Егорова Екатерина Александровна Врач УЗИ, ГАУЗ СО ГКБ № 14, г. Екатеринбург kaat333@mail.ru

Калабина Арина Сергеевна ФГБОУ ВПО «Уральский Государственный Медицинский Университет», г. Екатеринбург arina.kalabina@yandex.ru

Редькина Виктория Павловна ФГБОУ ВПО «Уральский Государственный Медицинский Университет», г. Екатеринбург vika.redkina.1999@mail.ru

Аннотация. Внебольничная пневмония бактериальной этиологии представляет большую эпидемиологическую и медицинскую значимость даже на фоне изменившейся ситуации в мире из-за широкого распространения вирусной пневмонии SARS-CoV-2. Несмотря на возможность установки точного этиологического диагноза и эффективную антибактериальную терапию, показатели заболеваемости и смертности, связанные с внебольничной пневмонией, сохраняются высокими. Большинство факторов риска смертности от внебольничной пневмонии давно определены, к ним можно отнести такие состояния как респираторная недостаточность, наличие некоторых сопутствующих заболеваний, социальная адаптация пациентов, но есть и ряд специфичных моментов для каждого региона.

Нашей задачей являлась оценка локальных факторов риска смертности от ВП и проведение сравнительного анализа данных с литературными источниками.

Ключевые слова: внебольничная пневмония, летальность, факторы риска.
B условиях текущей эпидемиологической ситуации, связанной с массовым инфицированием вирусом SARS-CoV-2, широкое распространение получила вирусная COVID-19-ассоциированная пневмония, в связи с чем множество лечебных учреждений были перепрофилированы для приема данных пациентов. Однако внебольничная пневмония (ВП) бактериальной этиологии все еще представляет большую эпидемиологическую и медицинскую значимость, и было бы ошибкой не уделять внимания данной нозологии.
В Российской Федерации заболеваемость ВП В 2018 году составила 491,67 на 100 тыс. населения, в 2019-518,9 на 100 тысяч при среднемноголетней заболеваемости 401,7 на 100 тысяч (2014-2018). Показатель смертности от ВП в среднем по стране в 2018 году составил 4,25 на 100 тыс. населения, в 2019-3,73 на 100 тыс. [2].

В Свердловской области заболеваемость ВП на 2019 год составила 814,5 на 100 тысяч населения, что выше уровня 2018 года на 37,7\%, 2017 - на 55,9\% и по- 
казателя заболеваемости по РФ на 57,4\%. Смертность в 2019 году составила 7,9 на 100 тысяч населения, что ниже показателя 2018 года - на 26,9\%, 2017 - на 32,3\% и среднемноголетнего уровня на $46 \%$. Согласно статистическим данным, показатель смертности формируется преимущественно за счет взрослого населения (99,1\%) $[3,9]$.

Таким образом, несмотря на возможность установки точного этиологического диагноза и эффективную антибактериальную терапию, показатели заболеваемости и смертности, связанные с внебольничной пневмонией, сохраняются высокими.

Учитывая широкую распространенность ВП, несколькими центрами был проведен анализ по выявлению предикторов летального исхода на фоне данного заболевания. Согласно данным канадских исследователей на основании оценки 1343 случаев ВП с клиническими и рентгенологическими признаками, факторами, независимо связанными со смертностью от пневмонии, были гипотермия, изменение психического статуса, повышенный уровень азота мочевины в сыворотке крови, хронические заболевания печени, лейкопения и гипоксемия [7]. К факторам, которые определяли прогноз при ВП, относились тип возбудителя пневмонии, привычные интоксикации, а также наличие сопутствующей патологии. Среди сопутствующих заболеваний чаще встречались хроническая обструктивная болезнь легких (ХОБЛ), сахарный диабет (СД), сердечно-сосудистые заболевания (СС3), иммунодефицит, хроническая болезнь почек, печеночная недостаточность и ревматические болезни [7, 10].

Согласно данным Харькова Е.И. были получены следующие результаты при определении факторов риска смертности у пациентов с ВП: к основным состояниям, приводящим к летальному исходу, относились в первую очередь дыхательная недостаточность (ДН) II-III степени, которая встречалась у 94\% пациентов, инфекционно-токсический шок (зарегистрирован в 27,6\% случаев), экссудативный плеврит у 9,8\% пациентов, и пневмоторакс у $2 \%[6]$.

В исследовании Поваляевой Л.В. при оценке сроков оказания медицинской помощи пациентам с ВП было определено среднее время от момента госпитализации до смерти, что составило 6,5 22,5 суток, при этом 30\% пациентов умерли в течение первых суток после госпитализации [4]. То есть, одним из факторов смертности данной когорты пациентов, являлась в том числе и скорость оказания первичной медицинской помощи.

При анализе социального статуса было выявлено, что среди умерших больных было достоверно больше неработающих лиц, в том числе неработающих лиц трудоспособного возраста; потребителей инъекционных и неинъекционных наркотиков; лиц, регулярно употребляющих алкоголь; курящих; ВИЧ-инфицированных; людей, проживающих в многонаселённой квартире, бараке или общежитии $[4,9]$. Наиболее распространенной сопутствующей патологией умерших пациентов с ВП являлись СС3 (30\%), хронические заболевания легких (15,5\%) и СД $(9 \%)[4,11]$.

В исследовании Eric M. Mortensen в качестве основных причин смерти у пациентов с ВП были дыхательная недостаточность и септический шок с последующей полиорганной недостаточностью, а также наличие сопутствующих СС3 [8]. В то же время ряд осложнений, которые многие клиницисты связывают с ВП, включая сепсис, бактериемию и полиорганную недостаточность, редко приводили к смерти в этой когорте. Независимые факторы, связанные со смертностью от ВП, были определены как пожилой возраст, измененное психическое состояние при поступлении в стационар, полисегментарная пневмония, септический шок на момент поступления, пневмококковая бактериемия и несовместимая эмпирическая антибактериальная терапия $[8,11]$.

То есть, большинство факторов в представленных выборках являются общими, но есть и ряд специфичных моментов для каждого региона.

Нашей задачей являлась оценка локальных факторов риска смертности от ВП и проведение сравнительного анализа данных с литературными источниками.

Проведен ретроспективный одномоментный анализ случаев ВП с летальным исходом на базе терапевтического отделения ГАУЗ СО «Городская клиническая больница № 14» города Екатеринбурга, произошедших в 2019 году с целью выявления возможных факторов риска смертности.

Для сравнения различий в социально-демографических и клинических характеристиках пациентов использовалась одномерная статистика. Причины смерти в зависимости от тяжести пневмонии и времени смерти были проанализированы с использованием простых описательных методов.

В данную выборку вошли 20 пациентов - 15 мужчин и 5 женщин (75\% и 25\% соответственно), из которых 35\% в возрасте старше 70 лет, 35\% - в возрасте от 30 до 39 лет, 15\% - от 40 до 49 лет, 15\% - от 50 до 65 лет.

Социальный статус больных был представлен различными категориями: пенсионерами являлись 8 чело- 
век (40\%), временно или постоянно не работающими 13 человек (65\%), работающими - 2 человека (10\%).

В анамнезе часто фигурировал факт хронической интоксикации алкоголем (у 50\% пациентов), наркотическими веществами (10\% случаев), при этом 15\% наркозависимых пациентов являлись ВИЧ-инфицированными.

Проявление первых симптомов заболевания отмечалось у пациентов в среднем за 5 дней до госпитализации. Все пациенты начали получать антибактериальную терапию в течение часа с момента госпитализации.

У всех пациентов была диагностирована полисегментарная пневмония, из них односторонняя локализация пневмонии имела место у $10 \%$ пациентов, а двусторонняя -у $90 \%$.

При анализе сопутствующей патологии выявлены хронические заболевания печени у 55\% пациентов, цереброваскулярная патология у $30 \%$, ожирение в $15 \%$ случаев. Также среди сопутствующей патологии встречались: хроническая сердечная недостаточность, ХОБЛ, СД 2 типа, онкологические заболевания (по 10\%).

Все пациенты были госпитализированы в отделение реанимации и интенсивной терапии (ОРИТ) для проведения искусственной вентиляции легких (ИВЛ). В 100\% случаев течение ВП осложнялось ДН II-ІІІ степени, в 95\% - отеком легких, в 35\% - плевритом, в 35\% - абсцедированием и в 20\% - инфекционно-токсическим шоком. 60\% пациентов умерли в течение суток после госпитализации, 20\% - на 2-3 сутки и 20\% - позднее 3 суток.
Согласно полученным данным, к некорригируемым факторам риска в нашей выборке пациентов относятся мужской пол, возраст старше 65 лет, отсутствие постоянной работы, алкоголизм, отклонение от нормы индекса массы тела, сопутствующие СС33 и хронические заболевания легких, двусторонний характер пневмонии.

Корригируемыми факторами риска в данном случае являются отсутствие амбулаторного лечения на ранних этапах развития симптоматики, госпитализация более 5 дней от начала заболевания и позднее первичное обращение за медицинской помощью (более 4 дней от появления первых симптомов).

Среди осложнений ВП, повлекших неблагоприятный исход, чаще всего развивались дыхательная недостаточность, отек легких, плеврит, абсцесс легкого.

Сравнительный анализ данных литературы и результатов исследования выявил совпадение факторов риска смертности при ВП. К ним относятся наличие у пациентов с ВП заболеваний СС3, хронические заболевания легких и СД, а также социальный статус пациентов.

На базе нашего учреждения основным фактором, определяющим прогноз пациента, стало развитие дыхательной недостаточности и отека легких, следующими по значимости являлись инфекционно-токсический шок и плеврит.

Таким образом, результаты проведенного исследования позволяют повысить настороженность врачей в отношении неблагоприятного исхода у определенных категорий пациентов и при осложненном течении заболевания.

\section{ЛИТЕРАТУРА}

1. Гордеева Н.В. Особенности тяжелого течения и летальных исходов внебольничных пневмоний на примере Красноярского края / Демко И.В., Корчагин Е.Е., Соловьева И.А. // Бюллетень физиологии и патологии дыхания.— 2019. -№ 74.—C. $26-33$.

2. 0 состоянии санитарно-эпидемиологического благополучия населения в Российской Федерации в 2019 году: Государственный доклад. - М.: Федеральная служба по надзору в сфере защиты прав потребителей и благополучия человека, 2020. -300 c.

3. 0 состоянии санитарно-эпидемиологического благополучия населения в Свердловской области в 2019 году: Государственный доклад.- - М.: Федеральная служба по надзору в сфере защиты прав потребителей и благополучия человека по Свердловской области, 2020. - 254 с.

4. Поваляева Л.В. Факторы риска смерти пациентов с внебольничной пневмонией в современных условиях / Л.В. Поваляева, Б.Е. Бородулин, Е.А. Бородулина, Г.Ю. Черногаева // Казанский медицинский журнал.— 2012.—Т. 93, № 5.—C. 816-820.

5. Хамитов Р.Ф. Внебольничная пневмония: немедикаментозные факторы риска летального исхода. // Пульмонология. — 2014 — № 1 - С. $23-26$.

6. Харьков Е.И. Анализ летальности от внебольничной пневмонии в КГБУЗ КМК БСМП им. Н.С. Карповича за 2012-2016 года / Харьков Е.И., Козлов Е.В., Бочкарева В.0., Бочкарев Д.В., Обухова И.А. // Здоровье и образование в XXI веке.— 2018. — № 4.—C. 76-78.

7. Thomas J. Marrie, 1 Keumhee C. Carriere, 2 Yan Jin, 4 and David H. Johnson3 Factors Associated with Death among Adults 55 Years of Age Hospitalized for CommunityAcquired Pneumonia Critical Care Medicine, University of Alberta, Research and Evidence, Alberta Health and Wellness, Edmonton, Alberta, Canada. Major Article ID2003:36

8. Eric M. Mortensen, MD, MSc; Christopher M. Coley, MD; Daniel E. Singer, MD; et alThomas J. Marrie, MD; D. Scott Obrosky, MSc; Wishwa N. Kapoor, MD, MPH; Michael J. Fine, MD, MSc Causes of Death for Patients With Community-Acquired Pneumonia Results From the Pneumonia Patient Outcomes Research Team Cohort Study Arch Intern Med. 2002;162(9):1059-1064. doi:10.1001/archinte.162.9.1059 
9. C. Garcia-Vidal, N. Ferna'ndez-Sabe, J. Carratala, V. Diaz, R. Verdaguer, J. Dorca, F. Manresa, F. Gudiol Early mortality in patients with community-acquired pneumonia: causes and risk factors Eur Respir J 2008; 32: 733-739 D0I: 10.1183/09031936.00128107 Copyright ERS Journals Ltd 2008

10. Sidnei Ferreiraa, Clemax C. Sant'Annaa, Maria de Fátima B.P. Marcha Lethality by pneumonia and factors associated to death Secretaria Municipal de Saúde, Rio de Janeiro, RJ, Brasil Recebido em 22 de fevereiro de 2013; aceito em 15 de maio de 2013

11. American Lung Association Epidemiology and Statistics Unit Research and Health Education Division November 2015 Trends in Pneumonia and Influenza Morbidity and Mortality

(c) Вишнева Елена Михайловна ( e.m.vishneva@mail.ru ), Егорова Екатерина Александровна ( kaat333@mail.ru ),

Калабина Арина Сергеевна ( arina.kalabina@yandex.ru ), Редькина Виктория Павловна ( vika.redkina.1999@mail.ru ).

Журнал «Современная наука: актуальные проблемы теории и практики»

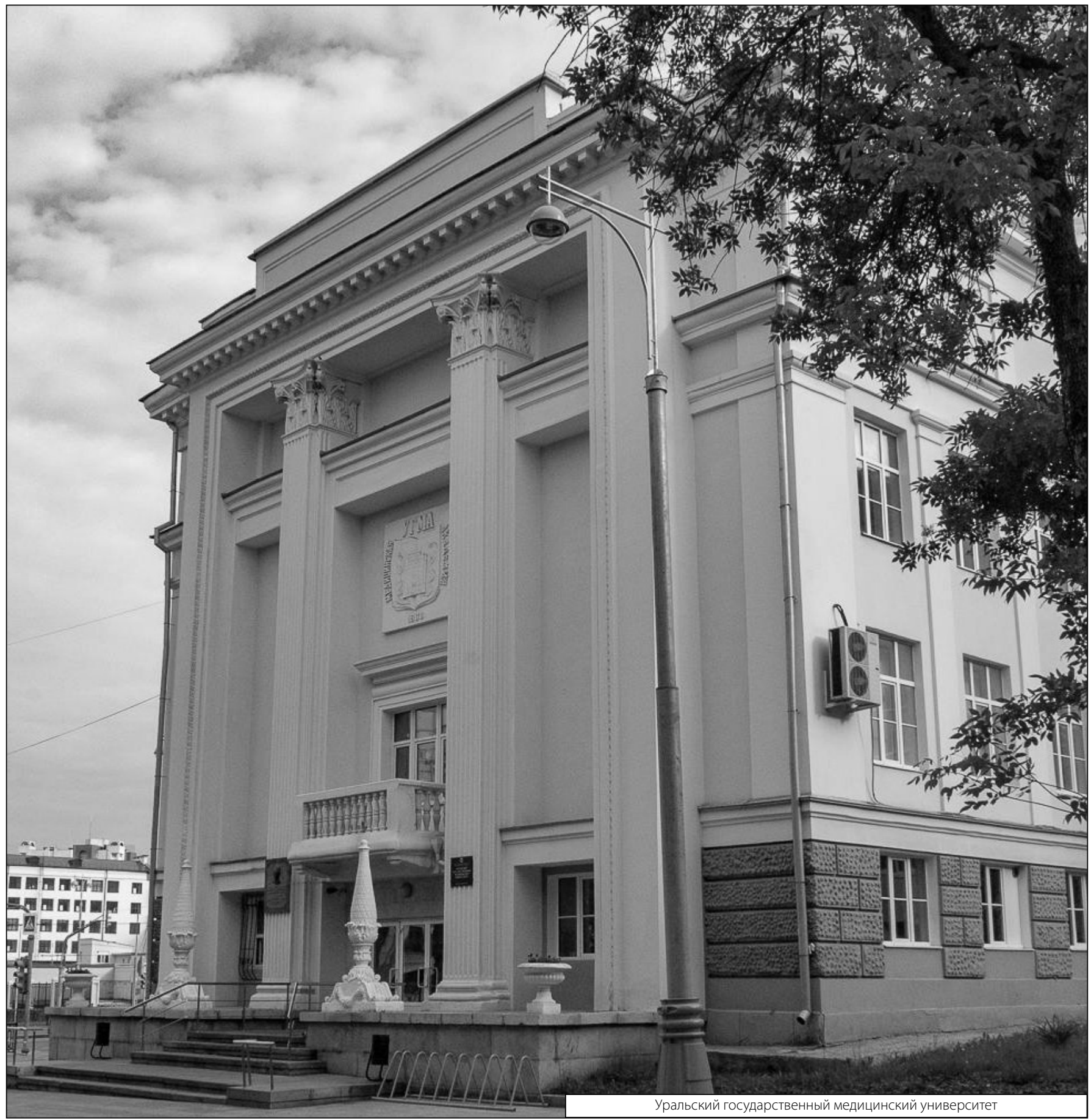

